\title{
Is there a role for Natural Desiccated Thyroid in the treatment of levothyroxine unresponsive hypothyroidism? Results from a Consecutive Case Series
}

\author{
Adrian Heald ${ }^{1}$, Lakdasa Premawardhana ${ }^{2}$, Peter N. Taylor ${ }^{3}$, Onyebuchi Okosieme ${ }^{2}$, \\ Tasneem Bangi ${ }^{4}$, Holly Devine ${ }^{4}$, Mark Livingston ${ }^{5}$, Ahmed Javed ${ }^{4}$, Gabriela Moreno ${ }^{6}$, \\ Torquil Watt ${ }^{7}$, Mike Stedman ${ }^{8}$, Colin Dayan $^{2}$, and Dyfrig Hughes ${ }^{9}$ \\ ${ }^{1}$ Salford Royal Hospitals NHS Trust \\ ${ }^{2}$ University of Wales Cardiff \\ ${ }^{3}$ Cardiff Univ \\ ${ }^{4}$ Salford Royal Hospital \\ ${ }^{5}$ Walsall Healthcare NHS Trust \\ ${ }^{6}$ Secretaria de Salud de Mexico \\ ${ }^{7}$ Affiliation not available \\ ${ }^{8}$ Res Consortium \\ ${ }^{9}$ Bangor University
}

September 24, 2021

\begin{abstract}
Introduction Some levothyroxine unresponsive individuals with hypothyroidism are prescribed a Natural Desiccated Thyroid

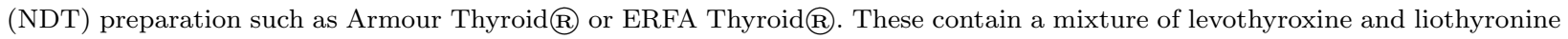
in a fixed ratio. We evaluated the response to NDT in individuals at a single endocrine centre in terms of how the change from levothyroxine to NDT impacted on their lives in relation to quality of life (QOL) and thyroid symptoms. Methods The ThyPRO39 (thyroid symptomatology) and EQ-5D-5L-related QoL)/EQ5D5L (generic QOL) questionnaires were administered to 31 consecutive patients who had been initiated on NDT, before initiating treatment/6 months later. Results There were 28 women/3men. The dose range of NDT was $60 \mathrm{mg}-180 \mathrm{mg}$ daily. Age range was 26-77 years with length of time since diagnosis with hypothyroidism ranging from 2-40 years. One person discontinued the NDT because of lack of response; 2 because of cardiac symptoms. EQ-5D-5L utility increased from a mean (SD) of 0.214 (0.338) at baseline, to 0.606 (0.248) after 6 months; corresponding to a difference of 0.392 (95\% CI 0.241-0.542), $\mathrm{t}=6.82, \mathrm{p}<0.001$. EQ-VAS scores increased from 33.4 (17.2) to 71.1 (17.5), a difference of 37.7 (95\% CI 25.2-50.2), $\mathrm{t}=-4.9, \mathrm{p}<0.001$. ThyPRO scores showed consistent fall across all domains with the composite QoL-impact Score improving from 68.3 (95\%CI 60.9-75.7) to 25.2 (95\% CI 18.7-31.7), a difference of 43.1 (95\%CI 33. -53.2) $(\mathrm{t}=5.6, \mathrm{p}<0.001)$. Conclusion Significant symptomatic benefit and improvement in QOL was experienced by people with a history of levothyroxine unresponsive hypothyroidism, suggesting the need for further evaluation of NDT in this context.
\end{abstract}

\section{Hosted file}

NDT_Thryoid_31 July 2021.docx available at https://authorea.com/users/312300/articles/538445is-there-a-role-for-natural-desiccated-thyroid-in-the-treatment-of-levothyroxineunresponsive-hypothyroidism-results-from-a-consecutive-case-series

\section{Hosted file}


Pre and post NDT Figures 1 and 2 on 9 August 2021.docx available at https://authorea.com/ users/312300/articles/538445-is-there-a-role-for-natural-desiccated-thyroid-in-thetreatment-of-levothyroxine-unresponsive-hypothyroidism-results-from-a-consecutive-caseseries

\section{Hosted file}

NDT Figure 3 on 9 August .docx available at https://authorea.com/users/312300/articles/ 538445-is-there-a-role-for-natural-desiccated-thyroid-in-the-treatment-of-levothyroxineunresponsive-hypothyroidism-results-from-a-consecutive-case-series

\section{Hosted file}

Table 11 NDT Populated 9 Aug 2021.docx available at https://authorea.com/users/312300/ articles/538445-is-there-a-role-for-natural-desiccated-thyroid-in-the-treatment-oflevothyroxine-unresponsive-hypothyroidism-results-from-a-consecutive-case-series 